\title{
САМОПІЗНАННЯ ЯК ПЕРЕДУМОВА ЕФЕКТИВНОСТІ ЖИТТЕВОГО ПРОЕКТУВАННЯ ЮНАКІВ
}

У статті відображаються результати теоретичного дослідження феномену «самопізнання» як передумови ефективності життєвого проектування юнаків. Проведено аналіз категорї̈ у філософській та психологічній науці, визначено основні підходи до розуміння його змісту. Здійснений аналіз наукових концепцій розкриває сутність феномену, його змістових характеристик, значення для саморозвитку $i$ самопобудови юнака. Перераховано иляхи, техніки та методи самопізнання, які безпосередньо або опосередковано допомагають заглянути у внутрішній світ. Розкрито взаємозв язок самопізнання з категоріями самооцінки, Я-образу, Я-концепції, самосвідомості, самодетермінації, довіри до себе. Наведено таблицю рівневої взаємозалежності довіри до себе та проектування. Результовано, щзо лише на базі комплексного самопізнання формується проект із влучного життєвого цүілеутворення, багатий на ефективність його реалізації та високу результативність.

Ключові слова: самопізнання, самоаналіз, самосвідомість, Я-концепція, самооцінка, самодетермінація, довіра до себе, особистісне та професійне самовизначення, життєве проектування.

B статье отражаются результаты теоретического исследования феномена «самопознание» как предпосылки эффективности жизненного проектирования юношей. Проведен анализ категории философской и психологической науке, определены основныле подходы к пониманию его содержания. Проведенный анализ научных концепџий раскрывает сущзность феномена, его содержательных характеристик, значение для саморазвития и самопобудовы юноши. Перечислено пути, техники и методы самопознания, которые прямо или косвенно помогают заглянуть во внутренний мир. Раскрыто взаимосвязь самопознания с категориями самооценки, Я-образа, Яконцепции, самосознания, самодетерминации, доверия к себе. Приведена таблица уровневой взаимозависимости доверия $к$ себе и проектирования. Результовано, что только на базе комплексного самопознания формируется проект по точного жизненного целеполагания, богатылй эффективность его реализации и высокую результативность.

Ключевые слова: самопознание, самоанализ, самосознание, Я-концепция, самооценка, самодетерминация, доверие к себе, личностное и профессиональное самоопределение, жизненное проектирования.

Постановка проблеми. Перший президент Асоціації гуманістичної психології, Джеймс Бьюдженталь вважає, що людина є істотою інтенціальною, тобто заглибленою в майбутнє. Вона не повинна бути пасивним спостерігачем процесу існування, а стати проектантом життя. Бути активним суб єктом життєтворчості, творцем неповторного шляху.

Науковці не так давно почали досліджувати проблему життєвого конструювання. Аналіз їхніх доробків показує динаміку протікання життєвого шляху, життєтворчості як здібності самодетермінованої особистості, характеристик темпоральності, каузально-атрибутивних обставин, темпу життя, особливостей цінісно-цільового планування та можливостей аксіопсихологічного проектування юнаків. Ці особливості відображаються у роботах : В. Зінченка, В. Ямницького, 
Д. Пузікова, I. Батраченко, I. Гуляса, I. Срмакова, К. Абульханової-Славської, О. Кроніка, 3. Карпенка, Н. Кириченко, О. Рихальської, С. Максименка, Т. Березіної, Т. Титаренко, С. Головахи, Є. Сергієнко та ін. Проте досліджень, що проходять на стику категорій самопізнання і життєвого проектування в науковій літературі є не так багато. Вони більше опосередковуються в інших напрямках досліджень (самосвідомості, рефлексії [6], самоаналізу тощо). А проблема самопізнання в юнацькому віці з точки зору психологічних механізмів формування і реалізації життєвого проекту вивчена не достатньо. Щоб забезпечити ефективність способів самобудови, ми досліджуємо дану проблему.

Аналіз останніх публікацій і досліджень. Теоретичний аналіз показує, що затвердження самої цінності самопізнання відбулося ще в античній Греції. Спочатку - в філософських, згодом - в релігійних, етичних, та психолого-педагогічних концепціях. На арці давньогрецького Дельфійського храму був начертаний напис «Пізнай самого себе», що означало: пізнай волю богів у своїй долі й підкорися їй. Давньогрецькі мислителі часів Сократа, Арістотеля, Платона, трактували цей девіз в такому розумінні: «пізнай своє призначення, відкрий свої можливості - і передбачиш поведінку». Підкреслюється також інтенціональність значення. За словами Р.Декарта, той, хто зможе розказати про себе все - може описати Всесвіт [2]. Тому що самопізнання відкриває закони світобудови, онтології плюралізму та супроводжується природним світлом розуму, тобто, інтуїцією, що невтомно шукає істину.

Самопізнання в психології є категорією окремих напрямків дослідження: 1) самосвідомості (вітчизняні - А. Захаров, В. Аверін, В. Столін, К. Абульханова-Славська, П. Чамата, О. Леонтьєв, С. Рубінштейн, В. Столін, зарубіжні - А. Адлер, А. Маслоу, Е. Фромм, З. Фрейд, К. Роджерс, К. Юнг, У. Джемс); 2) самоаналізу (А. Петровський, А. Хуторський, В. Зінченко, Г. Щедровицький, З. Фрейд, I. Бех, І. Зязюн, І. Шустова, К. Роджерс, К. Хорні, Л. Аврамчук, Л. Виготський, Л. Терлецька, М. Боришевський, О. Главацька, О. Крошка, О. Степанов, С. Максименко, С. Рубінштейн Ю. Трофімова); 3) рефлексї (А. Варданян, В. Давидов, В. Магкаєв, А. Зак, А. Карпов, В. Зарецький, В. Лефевр, В. Слободчиков, Г. Костюк, Г. Щедровицький, І. Семенов, Н. Гуткіна, О. Анісімов, О. Сиротіна, Р. Павелків, С. Степанов, С. Максименко, Л. Максимова, С. Ісаєв, С. Смирнов, Ю. Кулюткина, Є. Ісаєв); 4) самовиховання, самовдосконалення (А. Дістервег, В.Ягупов, Ж.-Ж. Руссо, Й. Песталоцці, К. Вентцель, К. Ушинський М.Пирогов); 5) саморозвитку (Л. Коган, Н. Бітянова, О. Кисельова, С. Маринчак); 6) самореалізації (А. Бойко, В. Андрєєва, В. Лозової, Л. Когана, М. Лазарєва, Л. Рибалко, Л. Сохань, О. Ларіна), 7) довіри до себе (Е. Фромм, Х. Ортега - Гассет, Е. Шостр, I. Антоненко, Н. Срмакова). Також ціленаправлено приділяється увага аналізу досліджень самоспостереження (як спостереження юнака за своїми діями, вчинками, прагненнями) i самообліку, що передбачає аналіз та оцінку своєї поведінки за певний час (В. Галузинський, Л. Рувінський, Л. Шаєва, Н. Масленнікова, О. Кочетов) та 8) морального самопізнання (М. Монтень, Дж. Локк, І. Кант, Г. Гегель).

Виклад основного матеріалу. Л. Виготський розглядав життєві плани як ефективний показник оволодіння особистістю своїм внутрішнім світом, пов'язюючи з ними "цільову" регуляцію абсолютно нового типу. 3 одного боку, внутрішній світ суб'єктивний і об`єднує наші думки, почуття, переживання, мрії, фантазії, сновидіння, багато іншого; з іншого - соціальний, оскільки включає в себе образи інших людей, їх дії і вчинки (Т. Березіна). Феномен самопізнання $\epsilon$ тим психологічним процесом і результатом, що $є$ фундаментом у прогностичних, гносеологіко-онтологічних вимірах індивідуального майбутнього. Завдяки активності самопізнання індивід (юнак) перестає бути продуктом зовнішніх обставин та набуває здатності до самотворення, життєвого проектування і самоактуалізації. О. Продан вважав взаємопов язаними процеси самопізнання, самоставлення та саморегулювання в структурі самосвідомості юнака.

Юнацький вік - сензитивний період самоусвідомлення, життєвих виборів та самостійності, становить період від 14-ти до 25-ти років. Самостійність не вичерпується здатністю індивідуально виконувати ті чи інші завдання. Вона включає ще більш істотну здатність свідомо ставити перед собою ті або інші цілі, визначати напрямок власної діяльності. Що вимагає великої внутрішньої роботи та передбачає здатність самостійно мислити. Лише у юнака відбувається ця робота так активно; виробляється критичне мислення, формується світогляд. До того ж наближення пори вступу в самостійне життя мимоволі $з$ особливою гостротою ставить перед юнаком питання про те, до чого він придатний, до чого має особливі схильності і здібності; змушує серйозніше замислитися над самим собою і призводить до значного розвитку самосвідомості юнака. Розвиток самосвідомості проходить при цьому через ряд ступенів - від наївного невідання щодо себе до все більш поглибленого самопізнання [8]. 
Самопізнання - це індивідуальний гносеологічний динамічний процес, об'єктом якого $є$ сам суб'єкт (юнак). Для релігійних юнаків самопізнання - це спосіб пізнання в собі Божественного начала, єднання з Богом. На рівні психології виступає засобом набуття психічного та психологічного здоров'я, гармонії, зрілості, здатності до саморозвитку, самовдосконалення, самоактуалізації .

Особливості досліджуваного феномену розкриває В. Моралов. Він аналізує онтогенетичну сторону самопізнання і описує його дворівневу структуру розвитку. І рівень «Я та Інші» здійснюється через різноманітні форми порівняння своєї персони 3 іншими людьми; II рівень - "Я та Я" передбачає оперування власними сформованими знаннями про себе та навчає утворенню нових. Інтенсивність, глибина і обгрунтованість процесу залежать від певних сформованих якостей юнака (наприклад, екстраверсія - інтроверсія). А рівень розвитку здібностей до самопізнання як до такого, дозволяє утворити знання про себе та керувати ними у власних цілях, або ж, - сформувати епізодично-фрагментарні (іноді неадекватні), що не відповідають дійсності, характеристики, які по суті не $\epsilon$ конгруентними в життєдіяльності їх носіїв [4].

Згідно того, яким чином відбувається самопізнання у дівчат та хлопців, виділяють загальні закономірності: 1) ступінь усвідомленості - неусвідомленості; 2) принцип постійної незавершеності та 3) принцип диференційованої насиченості [4]. Самопізнання активізується там, де життя насичене подіями. Юнацтво уособлює безліч таких можливостей: закінчення школи, складання ЗНО, вступ до університету, коледжу, технікуму, пошук роботи, заміжжя (одруження), пошук партнера і т.д. Раз-ураз необхідно самовизначатись, робити вибір, приймати нагальні рішення і нести за них відповідальність. На нашу думку, ніякий образ майбутнього, ніяке знання про нього, ніякий план чи життєва парадигма, нічого не може існувати до імперативу глибинного самопізнання юнака i усвідомлення себе суб єктом цього проектування. Структура “самопізнання - самоусвідомлення самомодель - самовдосконалення - саморегуляція" Г.Чернявської виділяє на початку ланцюга феномен самопізнання, позначаючи його первинним етапом даного процесу та підгрунтям ефективного структурування його наступних ланок [10, с. 31]. Ми погоджуємося з ним. Відповідно до цієї структуризації, перші два етапи розвитку (самопізнання і самоусвідомлення) входять до передумови і процесуальної частини життєвого проектування, а наступні три (самомодель, самовдосконалення, саморегуляція) $є$ похідними процесу реалізації проекту. Щодо змістової наповненості самопізнання, Г. Лейбніц вважає, що у розумі немає нічого, чого спочатку не було б у почуттях. Фізіологія перцепції пояснює, що інформація координується нейронними зв язками до головного мозку отримана 3 навколишнього середовища через органи дотику, зору, смаку та нюху i опрацьовується в локалізованих центрах. Вона, мовою психології, вимагає опрацьовання спеціальним інтелектуальним зусиллям, яке в полеміці Г. Лейбніца та Дж. Локка позначається «рефлексія».

Самопізнання - це початковий етап самовиховання особистості, вивчення нею своїх властивостей, системи цінностей, життєвих намірів, провідних мотивів і мотивацій, характеру, темпераменту, особливостей процесів пізнання (відчуття, сприйняття, уваги, мислення, пам'яті, мовлення). Самопізнання дає можливість самостійно визначити шляхи успіху в певній сфері діяльності, проаналізувати та удосконалити свою повсякденну діяльність [11]. У сучасних психологічних підходах існує ряд шляхів, технік та методів самопізнання, що безпосередньо або опосередковано допомагають заглянути у свій внутрішній стан молодій людині. Це: метод самоспостереження (С. Рубінштейн, А. Кочетов), самоаналізу (3. Фрейд), самообліку, самонагляду, самокритики, самоопитування, самоанкетування, згадування, зіставлення з іншими, самоперевірка, рефлексія [6], самопримушування, самовладання, самоконтроль (К. Абульханова-Славська, М. Боришевський), самонавіювання (3. Фрейд), самоставлення (Н. Сарджвеладзе), самоосуд, самопокарання, самопідбадьорювання, самосхвалення, перемога над собою, втілення бажаної поведінки в життя, самодіяльність(С. Рубінштейн), що вимагає від юнака-проектанта значних зусиль над собою. Виявлення індивідуальних характеристик індивіда; випробовування сил і можливостей у поєднанні зі ставлення до себе самого і з боку інших людей допомагають юнакові усвідомити його сильні та слабкі сторони. Як результат, формується самооцінка юнака - функціональний елемент самосвідомості, Я-образу, Я-концепції [5]. Остання у своїй структурі вміщає певні модальності: «Я духовне», «Я фізичне», «Я матеріальне», «Я соціальне» (У. Джеймс ), «Я реальне», «Я ідеальне» (К.Роджерс), «Я дзеркальне» (Ч.Кулі), «Я інтегральне» (М.Мід) та «Я професійне» (А.Реан, 3.Становських). Всі ці компоненти містять цілісне уявлення про юнака на рівні індивіда, рівні особи, рівні особистості, рівні індивідуальності. Я-концепція включає в себе не тільки наші уявлення про те, якими ми $\epsilon$, а й те, якими ми хотіли б бути - Я-ідеальне (за К.Роджерсом). Це всі ті характеристики, якими юнак мріє володіти, які найбільше цінує і до котрих тяжіє. За законами самодетермінації [1], іманентності, трансцендальності, рефлексії, мотивованості, вольових зусиль і конструктивного мислення в процесі проектування представляє можливість досягти бажаної «ідеальної» Я-концепції.

Випуск 11, 2018. Збірник наукових праць РДГУ 
На нашу думку, позитивна Я-концепція юнака-проектатора окрім психологічних елементів прийняття себе та позитивного ставлення до себе включає ще і піднесене ставлення до індивідуального життєвого проекту. Повага до власних планів і рішень сприяє активному опредметненню. В цьому випадку цільові елементи структури проекту і методологічні (практичні) шляхи його реалізації позбавляють суб`єкта внутрішньої амбівалентності, боротьби мотивів та різного роду когнітивних дисонансів. Позитивна Я-концепція виявляється джерелом ресурсивності. Виявляє бажання творити та віру в те, що все вдасться. Негативна як і амбівалентна Я-концепції в ході постановки цілей уособлюють невизначеність. Негативне ставлення юнака до себе, проекту та діяльності деструктує зміст і темп його реалізації . А неприйняття своєї суті вірогідніше, уможливлює утворення лише ілюзорних ідей, які не відповідають дійсності. Відчуття власної неповноцінності щоразу формується суб'єктивними сумнівами та коливаннями, що призводить до втрати енергії і зниження життєвого тонусу. На нашу думку, носій амбівалентної «Я-концепції»невизначена особистість, що не здатна стійко, постійно, цілеспрямовано реалізовувати свій проект. По відношенню до конкретних цілей чи завдань можна бути впевненим щодо результативності такого індивіда. Але у реалізації великих цілей варто не очікувати великої ефективності з його сторони. Постійні сумніви не дозволяють подивитися далеко у майбутнє та осягнути в інтелектуально-прогностичну форму його змісту. Співвідношення особистих домагань і реальних досягнень показують ступінь адекватності образу «Я». Який проявляється через завищений, адекватний чи занижений рівень самооцінки. Рівень самооцінки юнака певною мірою пов язаний із рівнем його довіри до себе. Довіра до себе як віра своїй інтроспекції, своїм відчуттям, сприйняттю, пам'яті, своїм інтерпретаціям - це віра і переконаність людини в своїй власній досконалості, це безумовна віра у свої сили, власну значимість, цінність, потрібність. Вона дозволяє відкрито висловлювати свої почуття і думки, діяти і бути впевненим у своїй в розумінні, підтримці, прощенні. Довіра до самого себе - перша необхідна умова великих починань (Джонсон Семюел) [3]. Можна простежити тісний взаємозв язок даного феномену (довіри до себе) не лише із психологічним утворенням самооцінки, а й з життєвим проектуванням як похідним від впливу віри у свої відчуття. Дослідник Є.Ільїн, спираючись на дослідження феномену «довіри до себе» Н.Астаніної та Т. Скрипкіної, демонструє межі феноменологічних проявів зростання рівня довіри особистості до себе 3 iii потенційними психологічними здібностями та життєтворчими можливостями [3, с. 47-48]. Ці особливості наведено у таблиці.

Табличя. 1

Феноменологічні прояви високого та низького рівня довери до себе

\begin{tabular}{|c|c|c|}
\hline № & Ознаки високого рівня довіри до себе & Ознаки низького рівня довіри до себе \\
\hline 1 & $\begin{array}{l}\text { Здатність до самостійного вибору і постановки } \\
\text { цілей, побудови стратегії ї } \\
\text { відповідно зі своїми цінностями }\end{array}$ & $\begin{array}{l}\text { Залежність в ухваленні рішення від думки інших, } \\
\text { постійний } \quad \text { пошук підтвердження } \\
\text { правильності свого вибору }\end{array}$ \\
\hline 2 & $\begin{array}{l}\text { Висока оцінка своїх можливостей, яка в умовах } \\
\text { невизначеності дозволяє людині відчувати себе } \\
\text { апріорно здатним до досягнення мети }\end{array}$ & $\begin{array}{l}\text { Низька оцінка своїх можливостей, яка в більшості } \\
\text { ситуацій, особливо невизначених, виражається в } \\
\text { переживаннях страху, невпевненості, сумнівів в } \\
\text { своїх здібностях досягти мети }\end{array}$ \\
\hline 3 & $\begin{array}{l}\text { Здатність орієнтуватися в ситуації, вибирати } \\
\text { прийнятні способи реалізації цілей відповідно до } \\
\text { умов в кожній конкретній ситуації }\end{array}$ & $\begin{array}{l}\text { Слабке орієнтування в ситуації з огляду на } \\
\text { переживання страху і надмірної фіксації на } \\
\text { досягненні позитивного результату }\end{array}$ \\
\hline 4 & $\begin{array}{l}\text { Здатність відстоювати свої кордони під тиском } \\
\text { зовнішніх обставин, впевнену поведінку на дорозі } \\
\text { досягнення цієї мети, засноване на переконанні в } \\
\text { правильності і цінності обраного ним шляху }\end{array}$ & $\begin{array}{l}\text { Переживання страху, сумнівів і невпевненості в } \\
\text { правильності ви лайливого шляху і способів } \\
\text { досягнення мети; висока ймовірність відмови від } \\
\text { способу досягнення мети або взагалі від мети під } \\
\text { тиском зовнішніх обставин }\end{array}$ \\
\hline 5 & $\begin{array}{l}\text { У разі невдачі характерно прощення собі } \\
\text { програшу при адекватній оцінці дій, які були } \\
\text { успішними, і зроблених помилок; пошук нових } \\
\text { способів досягнення мети }\end{array}$ & $\begin{array}{l}\text { При несприятливому результаті спроби досягти } \\
\text { мети характерна фіксація на невдачу } 3 \text { наступною } \\
\text { відмовою від вибору нових способів досягнення } \\
\text { мети }\end{array}$ \\
\hline 6 & $\begin{array}{l}\text { Ухвалення як свого успіху, так і невдачі на тлі } \\
\text { позитивного ставлення до себе }\end{array}$ & $\begin{array}{l}\text { Заперечення власного вкладу в успіхи і невдачі в } \\
\text { поєднанні з негативним ставленням до себе }\end{array}$ \\
\hline
\end{tabular}


Довіра до себе досить близько межує із самодетермінацією. Ї̈ї емпіричними критеріями $є$ спонтанність, креативність, інтерес і особистісна значимість як причини дії, почуття, відчуття себе вільним і такі психолінгвістичні індикатори, як переважання в мові дієслів "хочу" над "повинен" (Едвард Л. Десі, Річард М. Райан, 1991). Самодетермінація націлена на визначення факторів, які живлять вроджений людський потенціал, що визначає зростання, інтеграцію і здоров'я, і на дослідження процесів і умов, які сприяють здоровому розвитку і ефективного функціонування індивідів, груп і спільнот" (Ryan, Deci, 2000, p. 74) [1; 9].

Ми впевнені, що самодетермінація пов'язана із самопізнанням і $\epsilon$ чинником гармонізації особистості. У контексті аналізу численних психотерапевтичних бесід К.Роджерс узагальнює формулу самопізнання. У ній позначені етапи і змість когнітивних міркувань індивіда щодо себе. Мова йде про формування віри у стосунки з людьми, впевненість у самому собі, доречність свободи у прийнятті рішень, цінність особистісних змін і їх динаміки [7].

Отже, самопізнання - це імперативний психологічний механізм, що визначає вектор руху юнака у майбутньому як суб`єкта життєвого проектування. Виокремлює напрямки його цілеспрямованості, життєвої активності та професійної діяльності. Відповідно до самовизначення як кінцевого етапу самопізнання, визначається вид діяльності юнака, можливості та перспективи, яких він у майбутньому прагне досягнути та притримуватися їх, будучи самим собою та реалізуючи власну ентелехею.

Висновки та перспективи подальших розвідок. Самопізнання - це важлива складова юнацького життєтворчого процесу, що пронизує всю структуру особистості. Вона відповідає за внутрішню гармонізацію і впорядкування шляхом пізнання своїх талантів, здібностей, якостей, властивостей, власних сильних і слабких сторін, достоїнств і вад 3 ціллю використання або коригування їх у житті. Для того, щоб не допустити розчарування в собі, юнак повинен будувати своє майбутнє за принципом самодетермінації, довіри до себе, а високий рівень очікувань - замінити на високий рівень цілеспрямованості й домагань. Цільові утворення проекту фіксують точки свідомих потенційних досягнень.

Самопізнання як процес пов'язаний із такими підвалинами особистості, як: самоставлення особистості, самоповаги і самоприйняття; «сенсу життя», свободи і відповідальності; суб'єктивності, індивідуальної реальності, світогляду, картини світу; суб'єктивного духу, цінностей, орієнтацій; обдарованості, досвіду, таланту; самовизначення (особистого, професійного), саморегуляції, волі. Лише на базі комплексного самопізнання формується проект життєвого цілеутворення, багатий на ефективність його реалізації та високу результативність.

\section{Список використаних джерел}

1. Гордеева Т. О. Теория самодетерминации Э. Деси и Р. Райана. Психология мотивации достижения / Т. О. Гордеева. - М. : Смысл ; Академия, 2006. - 332 с.

2. Ждан А. Н. История психологии: от античности к современности : учеб. для студентов психол. спец. вузов / А. Н. Ждан. - М. : Акад. Проект, 2008. - 576 с.

3. Ильин Е. П. Психология доверия / Е. П. Ильин. - СПб. : Питер, 2013. - 288 с.

4. Маралов В. Г. Основы самопознания и саморазвития : учеб. пособ. для студентов сред. пед. учеб. заведений / В. Г. Маралов. - 2-е изд., стер. - М. : Академия, 2004. - 256 с.

5. Основи психології : підруч. для студентів вищ. навч. закл. / О.В.Киричук, В. А. Роменець, В. О. Татенко ; за загл. ред.: О. В. Киричука, В. А. Роменця. - 5-те вид. - Київ : Либідь, 2002. -632 с.

6. Особистість: внутрішній світ і самореалізація / упоряд. : Ю. Н. Кулюткин, Р. С. Сухобская. - СПб., 1996. - 13 с.

7. Роджерс К. Взгляд на психотерапию. Становлениечеловека / К. Роджерс. - М., 1994. $480 \mathrm{c}$. $720 \mathrm{c}$.

8. Рубінштейн С. Л. Основи загальної психології / Л. С. Рубінштейн - СПб. : Пітер, 2002. -

9. Самодетерминация : Психологіс : енциклопедія практ. психології [Електронний ресурс]. Режим доступу : http://psychologis.com.ua/samodeterminaciya.htm

10. Чернявська Г. К. Самопізнання і самореалізація особистості : метод. проблеми : автореф. дис. ... д-ра філос. наук / Г. К. Чернявська. - СПб., 1994. - 27 с.

11. Ягупов В. В. Педагогіка : навч. посіб. / В. В. Ягупов. - Київ : Либідь, 2002. - 560 с. 


\section{References}

1. Gordeyeva T. O. Teoriya samodeterminatsii E. Desi i R. Rayana [The theory of self-determination by E. Desi and R. Ryan] / T. O. Gordeyeva. - M. : Smysl, 2006. - 332 s.

2. Zhdan A. N. Istoriya psikhologii: ot antichnosti k sovremennosti [History of psychology: from antiquity to the present] / A. N. Zhdan . - M. : Acad. Project, 2008. -576 s.

3. Il'in Ye. P. Psikhologiya doveriya [Psychology of trust] / Ye. P. Il'in. - SPb. : Piter, 2013. - $288 \mathrm{~s}$.

4. Maralov V. G. Fundamentals of self-knowledge and self-development / V. G. Maralov. - 2d ed. M. : Acad. Publishing Center, 2004. - 256 s.

5. Kyrychuk O. V. Fundamentals of psychology / O. V. Kyrychuk, V. A. Romenets'. - 5d ed. - Kyiv : Lybid, 2002. - $632 \mathrm{s.}$

6. Kulyutkin YU. N. Personality: the inner world and self-realization / YU. N. Kulyutkin, R. S. Sukhobskaya. - SPb., 1996. - 13 s.

7. Rodzhers K. Vzglyad na psikhoterapiyu. Stanovleniyecheloveka [The thought of psychotherapy. Formation of a person] / K. Rodzhers. - M., 1994. - $480 \mathrm{~s}$.

8. Rubínshteyn S. L. Osnovi zagal'noí' psikhologíi' [Fundamentals of general psychology] / S. L. Rubínshteyn. - SPb. : Píter, 2002. - 720 s.

9. Samodeterminatsiya: Psikhologís. Yentsiklopediya praktichnoí' psikhologíi' [Self-determination: Psychology. Encyclopedia of practical psychology] [Electronic resource]. - Access mode : http://psychologis.com.ua/samodeterminaciya.htm

10. Chernyavs'ka G. K. Samopiznannya i samorealizatsiya osobystosti : metod. problemy : avtoref. dys. ... d-ra filos. nauk / G. K. Chernyavs'ka. - SPb., 1994. - 27 s.

11. Yagupov V. V. Pedagogíka [Pedagogy] / V. V. Yagupov. - Kil'’v : Libíd', 2002. - 560 s.

\section{A.O Shirokh SELF-KNOWLEDGE AS A PRECONDITION FOR THE EFFECTIVENESS OF YOUNG MEN LIFE DESIGNING}

The article presents the results of theoretical study of the phenomenon of "self-knowledge" as a precondition for the effectiveness of young men life designing. The analysis of the category in philosophical and psychological sciences is carried out, the main approaches to understanding its content are determined. The analysis of scientific concepts reveals the essence of the phenomenon, its content characteristics, the significance for self-development and self-building of young men. The basic areas of self-knowledge are determined, the most important of them are outlined in designing. The ways, techniques and methods of selfknowledge that directly or indirectly help to look into the inner world are listed. The relationships of selfknowledge with the categories of self-esteem, I-image and I-concept of young men are revealed. The features of low, high and adequate self-esteem, positive and negative I-concept are determined. The principle of self-determination, aimed at identifying the factors that nourish the innate potential, is noted. The factor of trust in hisrself recognizing the self-worth of the young man, his belief in feelings, introspection, selfimportance, necessity, forgiveness, support, which influence on the cognition and awareness of the personality of young man and is a necessary condition for great undertakings, is analyzed. The table shows the level of interdependence of self-confidence and design. Thus, it is understood that self-knowledge is an important component of a young men life-process that permeates the entire structure of the individual. This is an important precondition for the creation of a life project, which is a psychological factor in the formation of personal and professional self-determination; the mechanism of ensuring the adequacy, feasibility, relevance and constructiveness of building a life project. It is stated that a project is formed on the well-aimed life-goal formation only on the basis of complex self-knowledge and rich on effectiveness of It's realization and hight performance.

Key words: self-knowledge, self-examination, I-concept, self-evaluation, self-determination, trust in yourself, self-consciousness, personal self-determination, professional self-determination, project, life designing. 